\title{
Occurrence and diversity of myxomycetes (slime molds) in Polillo Island, Quezon Province, Philippines
}

\author{
Alexandra T. Viray ${ }^{1}$, Doxa Dave S. Rotap ${ }^{1}$, Louise L. Migraso ${ }^{1}$, Nicole Cezra I. Sibbaluca ${ }^{1}$, \\ Emilio Christian V. Escobar ${ }^{1}$, Anthony T. Buaya ${ }^{2}$, E Thomas Edison E. dela Cruz ${ }^{1,2 *}$ \\ ${ }^{1}$ Department of Biological Sciences, College of Science; ${ }^{2}$ Fungal Biodiversity and Systematics Group \\ Research Center for the Natural and Applied Sciences, University of Santo Tomas \\ España Boulevard, 1015 Manila, PHILIPPINES
}

\begin{abstract}
Myxomycetes in geographically isolated islands are among the less explored microbiota. The Philippines with its more than 7,000 islands offers many sites to study these island myxomycetes. In this study, the occurrence and diversity of myxomycetes in three forest sites within the island of Polillo are reported. Moist chambers were prepared for ground leaf litter and twigs collected within the island and used to assess myxomycete diversity. A total of 34 species were collected and identified in the island of Polillo. These were identified as belonging to the genera Arcyria, Ceratiomyxa, Comatricha, Collaria, Cribraria, Diachea, Diderma, Didymium, Echinostelium, Hemitrichia, Lamproderma, Lycogala, Perichaena, Physarum, Stemonitis, and Trichia. More species were recorded from ground leaf litter (24) than twigs (20). Two species, i.e. Arcyria cinerea and Cribraria microcarpa, occurred abundantly while 20 species were reported as rare. This research study is the first report of myxomycetes in the island of Polillo.
\end{abstract}

Keywords: island biodiversity, plasmodial slime molds, species abundance, species diversity

\section{INTRODUCTION}

Myxomycetes are well known to be present and common in island forests. According to Eliasson [1], geographically isolated islands are excellent natural laboratories of great interest to scientists involved in studies of evolution, biodiversity, and related fields. It is believed that the development of a great variety of habitats in an island favoured multiple evolutionary pathways

*To whom correspondence should be addressed tedelacruz@mnl.ust.edu.ph which were triggered because of geographic isolation, size, and topography. The Philippines which consists of over 7,100 islands is thus an ideal site to study island myxomycetes. At present, more than 120 species of myxomycetes are known in the country. These were only recorded from selected sites. For example, island myxomycetes were reported from Hundred Islands in Pangasinan [2] and Lubang Island in Occidental Mindoro [3]. These islands harboured eight new records for the Philippines. Nonetheless, despite these information, the 
number of myxomycetes in the country is still considered small. This means that there is still a lot of the country's tropical spots to be explored for myxomycetes.

The island of Polillo is a rich terrestrial ecosystem filled with forests, grasslands, and forest fragments [4]. The forest fragments are a result of habitat loss due to man-made activities such as slash-and-burn farming (“kaingin”) and illegal logging, making it one of the top hot spots for species conservation. In fact, island endemic taxa are still found to survive in these few patches of intact lowland rainforests and in watershed reserves amidst the island's increasing deforestation and forest loss due to the expanding agriculture and other anthropogenic activities. For example, some amphibians and reptiles surveyed in the island were reported as new species, i.e. Pseudogekkos maragdinus, Calotes marmoratus, and the forest frog Platymantis polilloensis [4]. These findings prove then that there are many organisms present that awaits discovery elsewhere in the island, and perhaps including species of myxomycetes. This study, as it is the first in the island, assesses the occurrence and diversity of myxomycetes in the island of Polillo, Quezon Province, Philippines.

\section{EXPERIMENTAL}

Study site. The island of Polillo (1446'28.78'N, $121^{\circ} 5^{\prime} 17^{\prime}$ 'E, elevation $56 \mathrm{~m}$ above sea level) is located in the province of Quezon, Southern Luzon, Philippines (Fig.1). It comprises of 27 islands with the main islands of Polillo, Patnanungan, Jomalig, and Palasin, and has a total land area of $761 \mathrm{sq} . \mathrm{km}$. The island is widely covered with forest growth. However, the northern part of the island is prone to illegal logging. The remaining forests are located in watersheds that provide valuable sources of potable water, timber, medicine, and food. These forests also serve as an important stronghold for many threatened and endemic species.
There is very little to no dry season throughout the year in the island. Southeast monsoon is from May to September while northeast monsoon is from October to April. The maximum rains occur during the months of November to January. Typhoons usually occur during the last quarter of the year [4]. Dominant forest trees within the island include antipolo (Artocarpus blancoi), narra (Pterocarpus indicus), batino (Alstonia macrophylla), anubing (Artocarpus rubrovenius), lanite (Kibatalia gitingensis), layasin (Maranthes corymbosa), takip-asin (Macaranga bicolor), and tibig (Ficus nota) [5].

\section{Sample collection and moist chamber (MC)} preparation. Thirty samples of each dried dead twigs (TW) and ground leaf litter (GL) were collected from three forest sites within the island of Polillo (Fig. 1). Forest site 1 (PI-S1: N1444'57.1”, E12157'19.8”), forest site 2 (PIS2: N1444'25.3”, E121'57'47.2”), and forest site 3 (PI-S3: N1443’43.8”, E12157’16.1”) are dominated by trees such as antipolo (Artocarpus blancoi) and narra (Pterocarpus indicus).

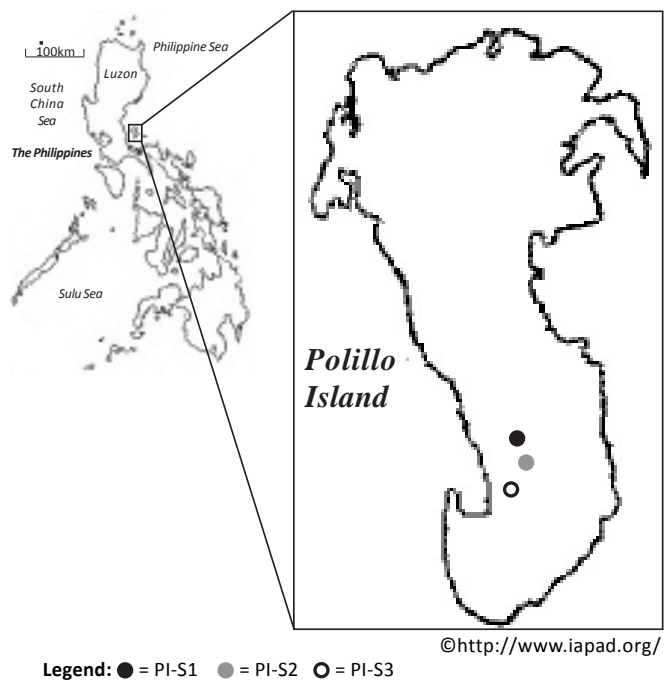

Figure 1. The study site: Lowland dipterocarp forest in Polillo Island, Quezon. 
Human activities have had no significant influence on the structure and composition of vegetation throughout the general study area except for the watershed found in proximity with PS-S1. There were little disturbances made by human activities to the surroundings such as some narrow human paths and a nipa hut found in an area inside the forest.

All collected substrates from these forest sites were immediately air-dried for at least a week prior to the preparation of moist chambers (MC). To prepare the MC, the collected samples were initially cut into small pieces and placed inside disposable Petri dishes lined with filter paper. Each sample was plated in triplicates. The substrates were then flooded with distilled water for $24 \mathrm{~h}$. The $\mathrm{pH}$ of the substrates was determined using a pH meter and the excess water was removed. The moist chambers were maintained at room temperature for 8 weeks (2 months). The presence of myxomycete plasmodia and/or fruiting bodies in the MC was checked at least once a week.

Voucher specimens were prepared for all species obtained from the MC and, with specimens directly collected in the field, were deposited at the Pure and Applied Microbiology Laboratory, Research Center for the Natural and Applied Sciences, University of Santo Tomas in Manila, Philippines.

Characterization and identification of myxomycetes. Photos of the fruiting bodies of collected myxomycetes were initially captured using Moticam (Moticam 1000) and a digital camera (Canon Ixus 6). The fruiting body characteristics were observed under a dissecting microscope and the following characters were noted: type, size, shape, appearance, and color of fruiting bodies, appearance of internal structures, e.g. capillitium, and the presence or absence of lime (calcium carbonate or $\mathrm{CaCO}_{3}$ ). Spore morphology was inspected by getting spores from the fruiting bodies and mounting them on a glass slide with $15 \%$ potassium hydroxide $(\mathrm{KOH})$ as mounting medium. Gathered morphometric data were compared with identification keys and published literature [6] and web-based electronic databases (http:// slimemold.uark.edu/). Names were based on the online nomenclatural database for eumycetozoan (http://nomen.eumycetozoa. com).

Ecological analysis. Initial ecological analysis involves the computation of the percent yield or productivity of the MC setups for all MC prepared and for each substrata and forest sites. The percent yield was calculated by dividing the number of MC with plasmodia/fruiting bodies by the total number of MC prepared [7].

To assess further the species diversity of myxomycetes in the island of Polillo, the relative abundance (RA) was first determined for all of the species recorded from the $\mathrm{MC}$ as described by Dagamac et al. [8]. Here, a MC positive for fruiting bodies of a specific myxomycete species is considered as one positive collection. Then, the RA for each species of myxomycetes were categorized as: (1) abundant (A) if RA is $\geq 10 \%$ of the total collections, (2) common (C) if RA is $\geq 5 \%$ but $<10 \%$ of the total collections, (3) occasional (O) if RA is $\geq 3$ but $<5$ of the total collections, and (4) rare (R) if the myxomycetes recorded an RA of $<3 \%$ of the total collections.

The taxonomic diversity (S/G ratio) was also assessed for the island of Polillo and for each substrate type and forest sites. Note that a lower $\mathrm{S} / \mathrm{G}$ ratio manifests a higher taxonomic diversity since a biota in which the species are divided among many genera is "intuitively" more diverse in a taxonomic sense than one in which most species belong to only a few genera [9].

On the other hand, species diversity using the Shannon Index $\left(\mathrm{H}_{\mathrm{S}}\right)$, species richness using the Gleason index $\left(\mathrm{H}_{\mathrm{G}}\right)$, and species evenness using the Pielou's (E) Index were computed based on 
relative abundance data as described by Dagamac et al. [8]. Community analysis of the myxomycete assemblages was done by comparing the species common to the different substrates and forest sites using the coefficient of community (CC) and the percentage similarity (PS) values as previously described by Stephenson [9]. Coefficient of community was based on the presence or absence of species of myxomycetes in the communities being compared while PS involved not just the presence or absence but also the relative abundances of each of the species.

\section{Results}

Checklist of myxomycetes in Polillo Island, Quezon. A total of 34 species of myxomycetes belonging to 16 genera were collected either from field collection (FC) and MC. Majority of the species (29) were observed in MC as compared to field collections (11). The myxomycetes that were identified are listed below, together with the sites of occurrence (PI-PS1, PI-PS2, PI-PS3), substratum (TW or GL) and collection source (FC or MC).

Arcyria afroalpina Rammeloo [PI-S1, PI-S2, PIS3; GL; MC]

A. cinerea (Bull.) Pers. [PI-S1, PI-S2, PI-S3; GL, TW; MC]

A. denudata (L.) Wettst [PI-S1, PI-S2, PI-S3; GL, TW; MC, FC]

A. glubosa Schwein [PI-S1, PI-S2; TW; MC]

A. pomiformis (Leers) Rostaf. [PI-S1; TW; MC]

Ceratiomyxa fruticulosa (O.F. Müll) T. Macbr. PI-S1, PI-S2; GL, TW; MC, FC]

Collaria arcyrionema (Rostaf.) Nann.-Bemek ex Lado [PI-S1, PI-S2; GL, TW; MC]

Comatricha tenerrima (M.A. Curtis) G. Lister [PI-S1, PI-S2, PI-S3; TW; MC]

C. typhoides (F.H. Wigg.) Rostaf. [PI-S3; GL, TW; MC]

Comatricha sp.1 [PI-S1; decayed wood; FC]

Cribraria microcarpa (Shrad.) Pers. [PI-S1, PIS2, PI-S3; GL, TW; MC]

C. violacea Rex [PI-S1, PI-S2, PI-S3; GL, TW; $\mathrm{MC}, \mathrm{FC}]$

Diachea bulbillosa (Berk. And Broome) Lister
[PI-S3; GL; MC, FC]

Diderma chondrioderma (de Bary \& Rostaf.) G. Lister [PI-S1; TW; MC]

D. effusum (Schwein.) Morgan [PI-S1, PI-S2, PI-S3; GL, TW; MC]

D. hemisphaericum (Bull.) Hornem. [PI-S3; GL, TW; MC]

Didymium iridis (Ditmar) Fr. [PI-S1, PI-S2, PIS3; GL; MC]

D. nigripes (Link) Fr. [PI-S2; decayed wood; $\mathrm{FC}]$

D. squamulosum (Alb. \&Schwein.) Fr. \& Palmquist [PI-S1, PI-S2; GL; MC]

Echinostelium minutum de Bary [PI-S1; GL; MC]

Hemitrichia calyculata (Speg). M.L. Farr [PIS1; TW; FC]

H. serpula (Scop.) Rostaf. Ex Lister [PI-S1, PIS2, PI-S3; GL, TW; MC, FC]

Lamproderma disseminatum Kowalski [PI-S1; GL, TW; MC]

L. scintillans (Berk. \& Broome) Morgan [PIS3; GL; MC]

Lycogala sp.1 [PI-S3; decayed wood; FC]

Perichaena depressa Lib. [PI-S1, PI-S2, PI-S3; GL, TW; MC]

P. dictyonema Rammeloo [PI-S2, PI-S3; GL, TW; MC]

This is the first record of this species in the Philippines. It was previously reported near the Matlalcueyetl Volcano in Mexico [10].

P. minor (G. Lister) Hagelst. [PI-S2; GL; MC] Physarum compressum Alb. \& Schwein [PIS1; TW; MC, FC]

P. globuliferum (Bull.) Pers. [PI-S3; GL; MC]

P. melleum (Berk.\& Broome) Massee [PI-S1, PI-S2; GL, TW; MC]

Stemonitis fusca Roth [PI-S3; GL, TW; MC]

Stemonitis sp.1 [PI-S1; bark; FC]

Trichia decipiens (Pers.) T. Macbr. [PI-S3; GL; $\mathrm{MC}]$

Percent yield, occurrence, and diversity of myxomycetes. A total of $540 \mathrm{MC}$ were prepared from GL and TW randomly collected from the three forest sites in Polillo Island, Quezon during the month of April 2012. Of the $540 \mathrm{MC}, 315$ or $61 \%$ yielded positive growth for myxomycetes. With respect to the substrata used, GL had a 

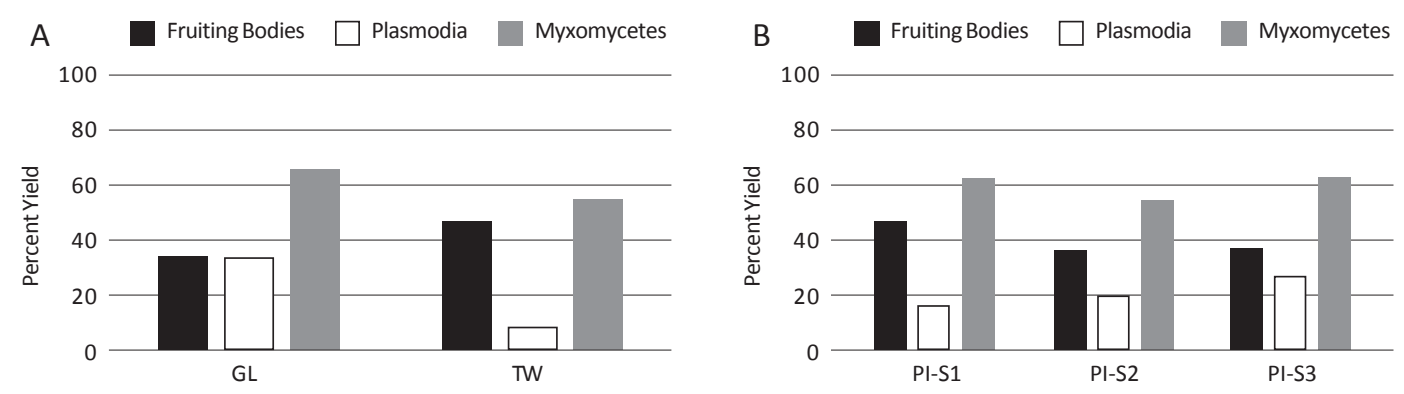

Figure 2. Percent yield of myxomycetes: (A) between two substrate types (ground leaf litter, GL and twigs, TW) and $(B)$ between the three forest sites.

yield of $66 \%$ while TW had a lower yield at $55 \%$ (Fig. 2). Comparing the forest sites, PI-S3 had the highest yield (64\%) followed by PI-S1 (63\%), and then, by PI-S2 (55\%). The relative abundance was also assessed for each of the forest sites and collected substrata (Table 1).

Two species were recorded as abundant in Polillo Island, i.e. A. cinerea and C. microcarpa. In contrast, there were 20 species recorded as rare. Between substrate types, $A$. cinerea and C. microcarpa were recorded as abundant in both substrates, while three species namely, $A$. cinerea, A. denudata, and C. microcarpa, were recorded as abundant on TW. Thirteen were rare for GL, and almost similar number of rare species was noted for twigs. For the three forest sites, one to two abundant species were recorded.

Results also showed that GL had the most number of genera (15) and species (24) as compared to TW which only had 11 genera and 20 species (Table 2). The lowest $\mathrm{S} / \mathrm{G}$ value and thus the most taxonomically diverse was also GL. On the other hand, comparing the taxonomic diversity of the three forest sites, PI-S3 (1.46) had the lowest S/G ratio compared to PI-S1 (1.66) and PI-S2 (1.70).

To further assess the species diversity, richness, and evenness, the relative abundance data from the MC setups were analyzed. Species diversity, i.e. the value of richness and evenness together in a study site, was highest in GL than in TW (Table 2). PI-S2 was found to be the most even and most diverse in terms of the species present. When the assemblages of myxomycetes were compared, a CC value of 0.70 was computed between TW and GL, while high CC value was accounted only for PI-S1 and PI-S2 (Table 3).

\section{Discussion}

Polillo Island is an ideal study site for island myxomycetes because of its geographic location and number of untouched and rich terrestrial ecosystems filled with forests, grasslands, and forest fragments [4]. Conservation of the biodiversity is a priority of the government due to the fact that unique species of organisms are found to be taking refuge in the island. In order for these conversation efforts to be successful, studying the biodiversity of the area including its microbiota is of necessity.

In the study, 34 species and 16 genera were recorded within the forest fragments in Polillo Island, Quezon. The results were seen to be related to such a degree with other studies of island myxomycetes in the country. For example, a total of 30 species of myxomycetes were reported from Hundred Islands National Park in Pangasinan [2] while another study in Lubang Island, Occidental Mindoro reported a total of 45 species of myxomycetes [3]. These previous data were recorded mainly from MC wherein $61 \%$ yielded positive growth for myxomycetes. 
Table 1. Relative abundance of myxomycetes recorded in Polillo Island

\begin{tabular}{|c|c|c|c|c|c|}
\hline \multirow{2}{*}{ Relative Abundance $^{a}$} & \multicolumn{2}{|c|}{ Substrates } & \multicolumn{3}{|c|}{ Forest Sites } \\
\hline & $G L$ & $T W$ & PI-S1 & PI-S2 & PI-S3 \\
\hline Arcyria afroalpina & 0 & & $\mathrm{R}$ & $\mathrm{R}$ & $\mathrm{R}$ \\
\hline A. cinerea & $A$ & A & A & A & A \\
\hline A. denudata & $\mathrm{O}$ & A & $\mathrm{C}$ & $\mathrm{C}$ & $\mathrm{C}$ \\
\hline A. glubosa & & $\mathrm{R}$ & $\mathrm{R}$ & $\mathrm{R}$ & \\
\hline A. pomiformis & & $\mathrm{R}$ & $\mathrm{R}$ & & \\
\hline Ceratiomyxa fruticulosa & $\mathrm{O}$ & $\mathrm{C}$ & $\mathrm{C}$ & $\mathrm{C}$ & \\
\hline Collaria arcyrionema & $\mathrm{O}$ & 0 & $\mathrm{R}$ & 0 & $\mathrm{C}$ \\
\hline C. tenerrima & & $\mathrm{R}$ & $\mathrm{R}$ & $\mathrm{R}$ & $\mathrm{R}$ \\
\hline C. typhoides & $\mathrm{R}$ & $\mathrm{R}$ & & & $\mathrm{R}$ \\
\hline Cribaria microcarpa & A & A & $\mathrm{C}$ & $\mathrm{C}$ & A \\
\hline C. violacea & $\mathrm{R}$ & $\mathrm{C}$ & $\mathrm{R}$ & 0 & 0 \\
\hline Diachea bulbillosa & $\mathrm{R}$ & & & & $\mathrm{R}$ \\
\hline Diderma chondrioderma & & $\mathrm{R}$ & $\mathrm{R}$ & & \\
\hline D. effusum & $\mathrm{C}$ & $\mathrm{R}$ & $\mathrm{R}$ & $\mathrm{C}$ & $\mathrm{R}$ \\
\hline D. hemisphaericum & $\mathrm{R}$ & $\mathrm{R}$ & & & $\mathrm{R}$ \\
\hline Didymium iridis & $\mathrm{R}$ & & $\mathrm{R}$ & $\mathrm{R}$ & $\mathrm{R}$ \\
\hline D. squamulosum & $\mathrm{O}$ & & $\mathrm{R}$ & $\mathrm{O}$ & \\
\hline Echinostelium minutum & $\mathrm{R}$ & & $\mathrm{R}$ & & \\
\hline Hematrichia serpula & $\mathrm{R}$ & $\mathrm{C}$ & $\mathrm{C}$ & $\mathrm{C}$ & $\mathrm{R}$ \\
\hline Lamproderma disseminatum & $\mathrm{R}$ & $\mathrm{R}$ & $\mathrm{R}$ & & \\
\hline L. scintillans & $\mathrm{R}$ & & & & $\mathrm{R}$ \\
\hline Perichaena depressa & $\mathrm{C}$ & $\mathrm{O}$ & $\mathrm{O}$ & $\mathrm{C}$ & $\mathrm{R}$ \\
\hline P. dictyonema & $\mathrm{O}$ & $\mathrm{R}$ & & $\mathrm{O}$ & $\mathrm{R}$ \\
\hline P. minor & $\mathrm{R}$ & & & $\mathrm{R}$ & \\
\hline Physarum compressum & & $\mathrm{R}$ & $\mathrm{R}$ & & \\
\hline P. globuliferum & $\mathrm{R}$ & & & & $\mathrm{R}$ \\
\hline P. melleum & $\mathrm{C}$ & $\mathrm{R}$ & $\mathrm{O}$ & $\mathrm{C}$ & \\
\hline Stemonitis fusca & $\mathrm{R}$ & $\mathrm{R}$ & & & $\mathrm{R}$ \\
\hline Trichia decipiens & $\mathrm{R}$ & & & & $\mathrm{R}$ \\
\hline
\end{tabular}

${ }^{a}$ Abundance Indices of myxomycetes per ground leaf litter (GL) and twigs (TW) and forest sites (PI-S1, PI-S2, PI-S3); Abundant (A): if relative abundance is $\geq 10 \%$ of the total collections; Common (C): if RA is $\geq 5 \%$ but $<10 \%$ of the total collections; Occasionally-occurring (O): if RA is $\geq 3 \%$ but $<5 \%$ of the total collections; Rare $(R)$ : if RA is $<3 \%$ of the total collections

Table 2. Taxonomic and species diversity of myxomycetes in Polillo Island, Quezon

\begin{tabular}{c|c|c|c|c|c|c|c}
\hline & $\begin{array}{c}\text { No. of } \\
\text { Collection }\end{array}$ & $\begin{array}{c}\text { No. of } \\
\text { Genera }\end{array}$ & $\begin{array}{c}\text { No. of } \\
\text { Species }\end{array}$ & $\begin{array}{c}\text { S/G } \\
\text { Ratio }\end{array}$ & Hs & Hg & E \\
\hline TW & 179 & 11 & 20 & 1.81 & 0.96 & 4.89 & 0.43 \\
\hline GL & 136 & 15 & 24 & 1.60 & 1.09 & 3.86 & 0.51 \\
\hline PI-S1 & 111 & 12 & 20 & 1.66 & 0.93 & 4.03 & 0.46 \\
\hline PI-S2 & 92 & 10 & 17 & 1.70 & 1.04 & 3.54 & 0.55 \\
\hline PI-S3 & 112 & 13 & 19 & 1.46 & 1.02 & 4.27 & 0.50 \\
\hline
\end{tabular}


Table 3. Sorensen's Coefficient of Community (lower left) and Percentage Similarity (upper right) values of the myxomycete communities collected at different forest types and substrates in Polillo Island.

\begin{tabular}{|c|c|c|c|c|c|c|}
\hline & GL & TW & & PI-S1 & PI-S2 & PI-S3 \\
\hline GL & $x$ & 0.93 & PI-S1 & $x$ & 0.91 & 1.01 \\
\hline \multirow[t]{2}{*}{ TW } & 0.70 & $x$ & PI-S2 & 0.81 & $x$ & 0.97 \\
\hline & & & $\mathrm{PI}-\mathrm{S} 3$ & 0.59 & 0.68 & $\bar{x}$ \\
\hline
\end{tabular}

It was also observed that GL had higher yield than dried TW. The same results were seen in the study of myxomycetes in Lubang Island, Occidental Mindoro [3], and in La Mesa Ecopark, Quezon City [7]. This is very interesting to note since Schnittler and Stephenson [11] concluded that litter-inhabiting myxomycetes reached their maximum diversity in the tropical moist forest. Hence, microhabitats could be a great factor in the data observed. A microhabitat was described simply as a microecosystem, i.e. a small specialized habitat within a larger habitat [11]. In this case, the microhabitat refers to the GL and dried TW.

Because the GL was more productive, it can be inferred that this substrate offers a better microhabitat for the growth of myxomycetes. This fact was further proven through the analysis of its taxonomic diversity (Table 2). In this study, the GL was noted to have an S/G ratio of 1.60 , and thus, were considered more taxonomically diverse than dried TW (1.81). This result was further supported through the analysis of species diversity (Table 2). Species diversity between the two substrata showed that GL was more species even $(\mathrm{E}=0.51)$ and diverse $(\mathrm{Hs}=1.09)$ as compared to dried TW.

It is interesting to note that there are species of myxomycetes that would grow better depending on the substrata used. In the study of Macabago et al. [3], substrates such as TW and leaf litter have minimal differences on their species composition. A similar study in another geographically isolated island in Costa Rica showed the same pattern of diversity with regards to the substrate type wherein leaf litter showed a higher species diversity than the woody substrates, i.e. Hs = 2.14 vs. 1.37 [12]. In addition, there were reports of $D$. squamulosum distributed regionally and that the species usually occurs in litter substrates in tropical forests [3].

This claim would then lead us to check the similarities of the communities in each substratum. Between the two substrates, a CC value of 0.70 and a PS value of 0.93 were recorded (Table 3). These results indicated that more than $70 \%$ of the total species identified were recorded in both substrates. In fact, 15 species were common between TW and GL. This data is relatively high, compared to the CC and PS values for GL and dried TW reported in other studies of island myxomycetes [3]. Apparently, only $30 \%$ of the species reported from MC exhibited substrate exclusivity. Since both substrates were collected in proximity, it is not surprising that the availability of decomposer bacteria that these myxomycetes prey upon [13], and the microclimate could be the same.

Myxomycete yield was also compared between the three forest sites. PI-S3 was most productive with the percent yield of $64 \%$, followed by PI-S1 (63\%), and then PI-S2 (55\%). It should be noted that PI-S2, the most elevated forest site, had the lowest myxomycete yield. It was reported by Schnittler \& Stephenson [12] that overall abundance and numbers of species of myxomycetes decreased with increasing elevation in Costa Rica. However, in this study, there is only a small difference in the elevation of the forest sites. Perhaps other factors such 
as the moisture level, airation rate, and temperature may have affected the results.

Evidence of human activities, i.e. presence of human trail paths and a nipa hut, were found in close proximity to PI-S2, thus disturbing the forest ecosystem and possible causing the decrease in the number of myxomycetes in the area. By determining the taxonomic diversity on each forest site, it was found out that PI-S3 was the most taxonomically diverse (Table 2). In terms of the species diversity with respect to each forest site, myxomycetes in PI-S2 (E = 0.55) was found to be more even than the other two sites, while PI-S1 $(E=0.46)$ was the least even.

Spores, food bacteria [13] and the microclimate [3] are factors to consider for the fruition of myxomycetes. Although PI-S2 had the lowest yield, there are still more species equitably distributed on this site, implying that these factors worked hand in hand to produce different kinds of species with a cost of a low yield. PI-S2 had evidences of human disturbances in the area, and this factor could also lead to the reason of its low yield.

On the other hand, PI-S3 had the highest species richness among the three sites $(\mathrm{Hg}=4.27)$. Assessing the overall diversity based on the Shannon's diversity index (Hs), PI-S2 with the index of 1.04 was the most diverse in terms of the species present. Moreover, among the three sites, PI-S1 which was near a watershed and PIS2 which was elevated, had the high CC (0.81) and PS (0.91) values. These results indicated almost $80-90 \%$ similarities in their species composition.

Arcyria cinerea and C. microcarpa were found to be abundantly occurring in these sampling sites. However, it was interesting to note that although Comatricha tenerrima was found on all three sites, this species was actually noted as rare in the analysis of its relative abundance.
This meant that there were species like $C$. tenerrima that occur on many sites but are less likely to produce many fruiting bodies.

\section{CONCLUSION}

A total of 315 specimens of myxomycetes were collected in Polillo Island, Quezon. These belonged to six taxonomical orders, 16 genera, and 34 species. Moist chambers prepared had $61 \%$ productivity, which was highest from GL samples. From the three forest sites, PI-S3 was the most productive followed by PI-S1, then by PI-S2. Arcyria cinerea and C. microcarpa were the most abundant myxomycetes in the study.

Analysis of taxonomic and species diversity showed that GL was more diverse than dried TW. Comparison of communities showed high similarity values between the two substrates. This scientific study was the first to report the occurrence and distribution of plasmodial myxomycetes in Polillo Island, Quezon.

\section{ACKNOWLEDGMENT}

The authors would like to thank the Research Center for the Natural and Applied Sciences of the University of Santo Tomas, Manila for the laboratory, research facility, and research grant for this study. The authors also extend their heartfelt gratitude to Mr. Ranie E. Fajardo and Mr. Matias B. Bulalacao of the Bantay KalikasanQuezon Chapter who served as our guide and aid within the forests of Polillo Island.

\section{REFERENCES}

[1] Eliasson UHA. Critical review of myxomycete records from the Hawaiian Islands. Systematic and Geography of Plants 2004; 74:81-86.

[2] Khun R, Javier AO, Rodillas C, Parra C, Corpuz LH, dela Cruz TEE, McHugh R. Occurrence and distribution of plasmodial myxmocycetes in Hundred Islands National Park, Pangasinan, Philippines. Acta Manilana 2011; 59:65-74. 
[3] Macabago SA, dela Cruz TE, Stephenson SL. First records of myxomycetes from Lubang Island, Occidental Mindoro, Philippines. Sydowia 2012; 64(1):109-118.

[4] Hampson K, Benett D, Alviola P, Clements T. Inventory of Forest Fragments in Polillo Island. Polillo Report Final Project 2002. http:// polillo.mampam.com/Summarypage.htm (February 20, 2012).

[5] Gonzalez JCT. Report on the Fauna and Flora Inventory of Priority Sites in the Polillo Islands Anibawan, Lipata and Carlagan. Pioneering Community-Based Conservation Sites in the Polillo Islands. (Polillo Islands Biodiversity Conservation Foundation Inc., Fauna \& Flora International and the Darwin Initiative for Conservation, UK; 2007).

[6] Stephenson SL, Stempen H. Myxomycetes: A Handbook of Slime Molds. (USA: Timber Press, Inc., 1994).

[7] Macabago S, Dagamac N, dela Cruz TE. Diversity and Distribution of Plasmodial Myxomycetes (Slime Molds) from La Mesa Ecopark, Quezon City, Philippines. Biotropia 2010; 17(2):51-61.
[8] Dagamac N, Stephenson SL, dela Cruz TE. Occurrence, distribution and diversity of myxomycetes (plasmodial slime moulds) along two transects in Mt. Arayat National Park, Pampanga, Philippines. Mycology 2012; 3(2):119-126.

[9] Stephenson SL, Kalyanasundaram I, Lakhanpal TN. A comparative biogeographical study of myxomycetes in the mid-Appalachians of eastern North America and two regions of India. Journal of Biogeography 1993; 20:645-657.

[10] Rojas C, Stephenson SL, Estrada-Torres A, Valverde $\mathrm{R}$, Morales $\mathrm{O}$. New records of myxomycetes from high-elevation areas of Mexico and Guatemala. Mycosphere 2010; 1:7382.

[11] Schnittler M, Stephenson SL. Inflorescence of Neotropical herbs as a newly discovered microhabitat for myxomycetes. Mycologia 2002; 94:6-20.

[12] Schnittler M, Stephenson SL. Myxomycete biodiversity in four different forest types of Costa Rica. Mycologia 2000; 92(4):626-637.

[13] Takahashi T, Hada Y. Distribution of Myxomycetes on coarse woody debris of Pinus densiflora at different decay stages in secondary forests of western Japan. Mycoscience 2009; 50:253-260. 